\title{
Biological Control of Bean Damping-off Caused by Sclerotium rolfsii \\ K.E. Eid
}

Agric. Bot. Dept., Fac. Agric., Moshtohor, Benha Univ., Egypt.

$\mathbf{T}$

The role of four bioagents, i.e. Bacillus subtilis, Pseudomonas 1 fluorescens, yeast (Saccharomyces cerevisiae) and Trichoderma viride, in controlling damping-off disease of bean (Phaseolus vulgaris L.) caused by Sclerotium rolfsii was evaluated under greenhouse and field conditions. The greenhouse experiment indicated that all the tested bioagents significantly reduced the incidence of the disease compared to control treatment. The most effective treatments were $B$. subtilis, $T$. viride and $P$. fluorescens which reduced disease incidence by more than 83.7 and $74.5 \%$ for pre- and post-emergence damping-off, respectively, while increased the plant survival by 90.3 , 86.1 and $87.6 \%$, respectively, compared to $26.3 \%$ in untreated plants. These treatments also increased the dry and fresh weights of bean shoot and root as well as resulted in considerable increases in the activities of peroxidase, polyphenoloxidase and chitinase by 260.0 , 109.0 and $218.3 \%$, respectively. Under field conditions, all the tested bioagents significantly reduced disease incidence with considerable increases in plant survival and higher seed yield during the two seasons (February of 2009 and 2010) of study. During the first season, B. subtilis T. viride, S. cerevisiae and P. fluorescens were found to be the most effective bioagents which reduced the disease incidence with more than 61.3 and $41.3 \%$ than the control for pre- and postemergence damping-off, respectively. The corresponding percentages of survived plants were $78.2,79.0,75.2$ and $76.8 \%$, respectively, viz. $38.5 \%$ for the control. On the other hand, the most effective treatments for increasing seed yield were $S$. cerevisiae followed by P. fluorescens, being 894.95 and $748.1 \mathrm{~kg} /$ feddan viz. $269.2 \mathrm{~kg} / \mathrm{feddan}$ for the control. The other two bioagents showed moderate effect. The same trend was obtained during the second season. It could be suggested that such bioagents might be promising as alternatives to synthetic fungicides for controlling bean damping-off caused by S. rolfsii.

Keywords: Bean, bioagents, enzymes, Sclerotium rolfsii and seed yield.

Bean plants (Phaseolus vulgaris L.) are one of the most important leguminous crops in Egypt. Damping-off disease is a serious and persistent problem of bean plants during growing season (Filion et al., 2003; Harveson et al., 2005 and Wen et al., 2005). Sclerotium rolfsii Sacc. [Athelia rolfsii (Curzi) Tu \& Kimbrough] causes a disease known as southern blight or white mould in a wide variety of crops all over the world. Sclerotium root-rot disease is difficult to manage since the fungal sclerotia can survive for several years in soil and crop residues (Punja, 1985). 
Nowadays, the world is suffering from pollution caused by the extensive uses of the agrochemicals in agriculture such as pesticides. Therefore, the plant pests, especially of vegetables and fruits, could be more preferably controlled using more safe methods than pesticides. This work aimed at using bioagents for controlling bean damping-off. The biological control of plant pests using antagonistic microorganisms is a potentially, non-chemical means of controlling plant disease by reducing inoculums level of the pathogens. Such management could help in preventing pollution and no health hazards (Kumar, 2007). Trichoderma spp. are the most popular bioagents that have been extensively researched and deployed throughout the world (Khalifa et al., 2013). Bacillus spp., Pseudomonas spp. and yeast (Saccharomyces cerevisiae) are also among the most important genera of the antagonistic microorganisms for controlling fungal diseases (Meena et al., 2001, Ibrahim et al., 2008 and Abdel-Kader et al., 2012). Bacillus subtilis reduced damping-off and root-rot diseases of many crops under greenhouse and field conditions (El-Fiki et al., 2004; Mahmoud et al., 2006 and Khalifa et al., 2007). Pseudomonas fluorescens is also an important antagonistic bacterium against several soil borne pathogens (Jayashree et al., 2000 and Karunanithi et al., 2000).

The present study aimed to evaluate the effect of different bioagents, i.e. $S$. cerevisiae, $T$. viride, B. subtilis and $P$. fluorescens on controlling $S$. rolfsii, in beans compared to the fungicide Vitavax-200 under greenhouse and field conditions.

\section{Mat e rials and Methods}

Source of the materials:

A white mouldy layer with small, smooth and brown sclerotia was detected in the parts of common beans in contact with the soil which was initially identified as Sclerotium rolfsii infection according to Schwartz et al. (2005) and Anonymous (2007). Further confirmation of $S$. rolfsii was performed through the morphological characteristics identified under the microscope by the Dept of Mycol. Res. and Dis. survey, Plant Pathol. Res. Inst., ARC. The tested bioagents, i.e. Trichoderma viride, Bacillus subtilis and Pseudomonas fluorescens, were kindly obtained from Botany Dept., Fac. of Agric., Benha Univ. Meanwhile, yeast (Saccharomyces cerevisiae) was obtained from Microbiol. Res. Centre, Cairo MIRCEN, Ain Shams Univ., Egypt. Bean seeds (cv. Bronco) were obtained from Veg. Crops Res. Dept., ARC, Giza, Egypt.

Greenhouse experiments:

Effect of the tested bioagents on incidence of damping-off:

The antagonistic bacteria, i.e. P. fluorescens and B. subtilis, were grown in nutrient broth medium, while yeast ( $S$. cerevisiae) was grown on nutrient yeast dextrose broth medium NYDB (Abd-Alla et al., 2007). All tested bacteria and yeast were incubated in a rotary shaker at $200 \mathrm{rpm}$ for $48 \mathrm{~h}$ at $28 \pm 2^{\circ} \mathrm{C}$. The suspensions of the bacterial and yeast cells were adjusted to $3 \times 10^{6} \mathrm{cfu} / \mathrm{ml}$ (Omar et al., 2011). Both $T$. viride and $S$. rolfsii were grown in $500 \mathrm{ml}$ glass bottles contained autoclaved sand-barley medium (1:3 w:w and $40 \%$ water). Autoclaved bottles, containing the medium, were inoculated with any of $S$. rolfsii and $T$. viride and incubated at $28 \pm 2^{\circ} \mathrm{C}$. for 15 days. 
Plastic pots (25-cm-diam.) were sterilized by dipping in 5\% formalin solution for 5 minutes, then thoroughly washed with tap water and left to get rid of the remained formalin, then filled with sandy loam soil sterilized with $5 \%$ formalin solution and left to aerate. Pots were infested with $S$. rolfsii inoculum at the rate of $3.0 \%(\mathrm{w} / \mathrm{w})$. After 14 days of soil infestation, T. viride was applied at a rate of $5 \%(\mathrm{w} / \mathrm{w})$, meanwhile, either antagonistic bacteria or yeast were used at a rate of $50 \mathrm{ml} / \mathrm{pot}$ (each $1 \mathrm{~m}$ contains about $3 \times 10^{6}$ cells (Abdel-Kader et al., 2012). Seeds moisten with super film as sticker, were dressed with Vitavax-200 at a rate of $3 \mathrm{~g} / \mathrm{kg}$ seed were used for comparison. Five surface sterilized bean seeds with $2 \%$ sodium hypochlorite (cv. Bronco) were sown in each pot. Five replicates were used for each treatment. Pots infested with the pathogenic fungus and sown with untreated sterilized seeds were used as control. Percentages of pre- and post-emergence damping-off as well as healthy survived plants were recorded 15, 30 and 60 days after planting, respectively. Fresh and dry weight of shoot and root systems were determinate at the end of the experiment (60 days after planting).

Determination of enzymes activity:

The four tested bioagents as well as the fungicide Vitavax-200 were evaluated for their effects on the activities of peroxidase, polyphenoloxidase and chitinase enzymes in bean plants.

Extraction of enzymes:

Five grams of bean leaves were taken 6 weeks after sowing and ground in a mortar in presence of purified sand plus $4 \mathrm{~mL}$ of $0.1 \mathrm{M}$ sodium phosphate buffer (pH 7.1) (Tuzun et al., 1989). The homogenate of each sample was filtered through four layers of cheesecloth then the filtrates were centrifuged at $3000 \mathrm{rpm}$ for $20 \mathrm{~min}$. at $6^{\circ} \mathrm{C}$. The obtained supernatant fluids (crude enzyme extracts) were used for assaying activities of peroxidase, polyphenoloxidase (PPO) and chitinase enzymes at 425, 420 and 540nm, respectively, using spectrophotometer (Spectronic 20-D). Enzyme extract was replaced by distilled water in controlling blank cuvette. Changes in absorbency for all previous enzymes were recorded. In this regard, the activity of peroxidase enzyme (Allam and Hollis, 1972), polyphenoloxidase enzyme (Matta and Diamond, 1963) and Chitinase enzyme (Boller and Mauch, 1988) were determined.

\section{Field experiments:}

A field originally contaminated with $S$. rolfsii, (located at the vegetable farm of Horticulture Dept., Fac. of Agric. Moshtohor, Benha Univ., Egypt) was chosen to evaluate the effectiveness of the tested bioagents, i.e. B. subtilis, P. fluorescens, $S$. cerevisiae and $T$. viride, in reducing the damping-off incidence and their further effects on the seed yield during the two seasons (February of 2009 and 2010) of study. Physical and chemical properties of the soil of study are presented in Table (1). A field experiment was conducted in Complete Randomized Block Design with three replicates (plots) for each treatment as well as control. The plots area were $10.5 \mathrm{~m}^{2}(3 \times 3.5)$, each comprised of 3 rows and 16 hill/row. Bean seeds (cv. Bronco) were used in all treatments at rates of 2 seeds/hill. 
Table 1. Physical and chemical analyses of field soil during two growing seasons of 2009 and 2010

\begin{tabular}{|l|c|c|}
\hline \multicolumn{1}{|c|}{ Soil characteristic } & 2009 & 2010 \\
\hline Coarse sand $(\%)$ & 2.0 & 2.2 \\
\hline Fine sand $(\%)$ & 23.4 & 24.7 \\
\hline Silt $(\%)$ & 33.4 & 36.0 \\
\hline Clay $(\%)$ & 41.1 & 46.4 \\
\hline Textural class & Clay loam & Clay loam \\
\hline CaCO $\left(\mathrm{g} \mathrm{kg}^{-1}\right)$ & 25.1 & 22.1 \\
\hline Organic matter $\left(\mathrm{g} \mathrm{kg}^{-1}\right)$ & 1.5 & 1.3 \\
\hline pH & 7.8 & 2.7 \\
\hline EC $\left.(\mathrm{dS} \mathrm{m})^{-1}\right)$ & 2.4 & 2139.0 \\
\hline Total N $\left(\mathrm{mg} \mathrm{kg}^{-1}\right)$ & 1154.0 & 41.1 \\
\hline Available P $\left(\mathrm{mg} \mathrm{kg}^{-1}\right)$ & 43.1 & 688.0 \\
\hline Available K $\left(\mathrm{mg} \mathrm{kg}^{-1}\right)$ & 976.0 & \\
\hline
\end{tabular}

Soil infestation with inocula of the tested bioagents was carried out by using $360 \mathrm{~g}$ of $T$. viride inoculum/row and $500 \mathrm{ml}\left(3 \times 10^{6} \mathrm{cfu} / \mathrm{ml}\right)$ of $B$. subtilis, $P$. fluorescens and $S$. cerevisiae inoculum /row by incorporating the inoculum on the top $20 \mathrm{~cm}$ of soil surface of the rows before sowing (El-Mougy, 2001). Seeds were dressed by Vitavax-200 at a rate of $3 \mathrm{~g} / \mathrm{kg}$ seed were used for comparison.

Disease assessment of pre- and post-emergence damping-off as well as survived plants was recorded 15, 30 and 60 days after planting, respectively. Fresh and dry weights of the plants were determined at flowering stage by selecting five plants randomly from each plot. Beans pods of each plot were harvested at proper maturity stage, and then weighed then total seed yield/feddan was estimated.

Statistical analysis:

Data collected were analysed with the statistical analysis system (Anonymous, 2005). All multiple comparisons were first subjected to analysis of variance (ANOVA). The differences between the mean values of various treatments were compared by Duncan's multiple range test (Duncan, 1955).

\section{R e s u l t s}

Effect of four bioagents compared to the fungicide Vitavax-200 on incidence of damping-off under greenhouse conditions:

Data presented in Table (2) and Fig. (1) indicate that all the tested bioagents significantly reduced pre- and post-emergence damping-off caused by $S$. rolfsii compared to untreated control. In addition, the most effective bioagent in this regard was $B$. subtilis followed by $P$. fluorescens then $T$. viride, which reduced the disease more than 83.7 and $74.5 \%$ for pre- and post-emergence damping-off. The respective averages of survived plants for these bioagents were 90.3, 86.1 and 87.6\%, respectively, compared to $26.3 \%$ for untreated plants. Meanwhile, S. cerevisiae reduced pre- and post-emergence damping-off by 79.7 and $44.0 \%$, respectively, with $77.5 \%$ survived plants. 
Table 2. Effect of bioagents and the fungicide Vitavax-200 on incidence of bean (cv. Bronco) damping-off under the greenhouse conditions

\begin{tabular}{|l|c|c|c|c|c|}
\hline \multicolumn{1}{|c|}{ Treatment } & $\begin{array}{c}\text { Pre-emergence } \\
\text { Damping-off }(\%)\end{array}$ & $\begin{array}{c}\text { Reduction } \\
(\%)\end{array}$ & $\begin{array}{c}\text { Post-emergence } \\
\text { Damping-off }(\%)\end{array}$ & $\begin{array}{c}\text { Reduction } \\
(\%)\end{array}$ & $\begin{array}{c}\text { Survived } \\
\text { plants }(\%)\end{array}$ \\
\hline S. cerevisiae & $10.7 \mathrm{~b}$ & 79.7 & $11.7 \mathrm{bc}$ & 44.0 & $77.5 \mathrm{~b}$ \\
\hline$T$. viride & $8.6 \mathrm{~b}$ & 83.7 & $5.3 \mathrm{~cd}$ & 74.5 & $86.1 \mathrm{ab}$ \\
\hline B. subtilis & $5.9 \mathrm{~b}$ & 88.8 & $3.8 \mathrm{~d}$ & 81.8 & $90.3 \mathrm{a}$ \\
\hline P. fluorescens & $7.2 \mathrm{~b}$ & 86.4 & $5.2 \mathrm{~cd}$ & 75.2 & $87.6 \mathrm{ab}$ \\
\hline Vitavax-200 & $12.8 \mathrm{~b}$ & 75.8 & $12.1 \mathrm{~b}$ & 42.3 & $78.6 \mathrm{~b}$ \\
\hline Control & $52.8 \mathrm{a}$ & 00.0 & $20.9 \mathrm{a}$ & 00.0 & $26.3 \mathrm{c}$ \\
\hline
\end{tabular}

Values with the same letter are not significantly different $(\mathrm{P}=0.05)$.

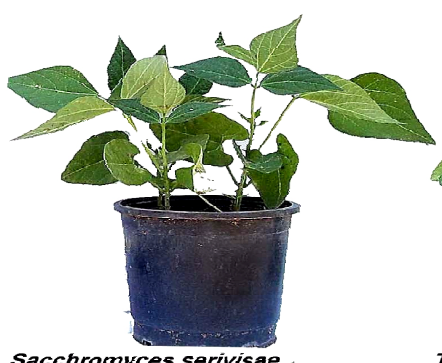

Sacchromyces serivise

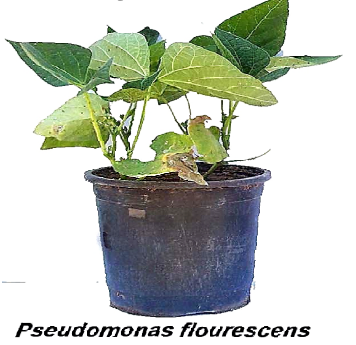

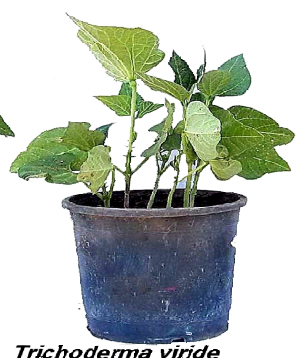

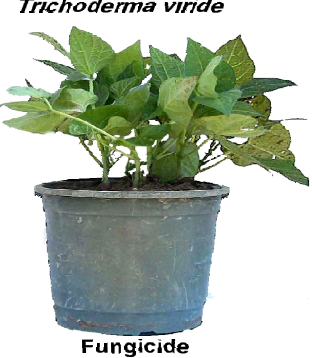

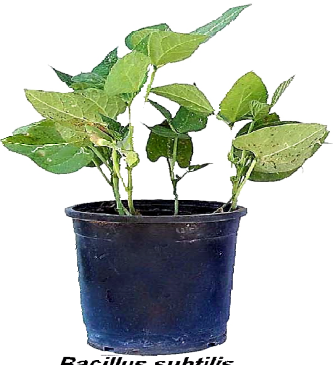

Bacillus subtilis

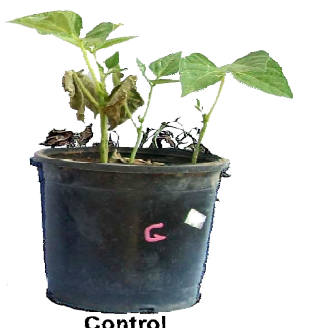

Fig. 1. Effect of four bioagents, i.e. yeast (S. cerevisiae), T. viride, B. subtilis and $P$. fluorescens, on growth of bean plants infested with $S$. rolfsii under greenhouse conditions.

Effect of four bioagents compared to the fungicide Vitavax-200 on fresh and dry weight of shoot and root system of bean plants under greenhouse conditions:

Data shown in Table (3) reveal that all the tested bioagents significantly increased shoot and root fresh and dry weight compared to untreated control. The highest increases in root and shoot dry weights were recorded for yeast (S. cerevisiae) treatment. Pseudomonas fluorescens recorded statistically similar effects to those of the fungicide treatment on root and shoot dry weights. Although there were no statistical differences between $T$. viride and B. subtilis and that of the fungicide treatment on the root dry weight, while their effects were significantly lower than that of the fungicide treatment on shoot dry weight. 
Table 3. Effect of some bioagents compared to the fungicide Vitavax-200 on fresh and dry weight for shoot and root system of bean plants (cv. Bronco) under greenhouse conditions

\begin{tabular}{|l|c|c|c|c|}
\hline \multirow{2}{*}{ Treatment } & \multicolumn{2}{|c|}{$\begin{array}{c}\text { Shoot system weight } \\
(\mathrm{g} \text { plant }\end{array}$} & \multicolumn{2}{c|}{$\begin{array}{c}\text { Root system weight } \\
(\mathrm{g} \text { plant }\end{array}$}
\end{tabular}

Values with the same letter are not significantly different $(\mathrm{P}=0.05)$.

Effect of four bioagents compared to the fungicide Vitavax-200 on the enzymatic activity of bean plants.

Data presented in Table 4 reveal that all treatments increased the activity of all the assessed enzymes compared to untreated control. Generally, all the tested bioagents were superior for increasing the activity of all the tested enzymes compared to the tested fungicide. $T$. viride resulted in the highest increase in the activity of chitinase and polyphenoloxidase, whereas $B$. subtilis caused highest increase in the activity of peroxidase.

Table 4. Effect of four bioagents on the enzymatic activity of bean plants (cv. Bronco) plants

\begin{tabular}{|l|c|c|c|c|c|c|}
\hline \multirow{2}{*}{ Treatment } & \multicolumn{2}{|c|}{ Chitinase } & \multicolumn{2}{c|}{ Peroxidase } & Polyphenoloxidase \\
\cline { 2 - 7 } & Activity $^{(1)}$ & $\begin{array}{c}\text { Increase } \\
(\%)\end{array}$ & Activity $^{(2)}$ & $\begin{array}{c}\text { Increase } \\
(\%)\end{array}$ & Activity $^{(3)}$ & \begin{tabular}{c} 
Increase $_{(\%)}$ \\
\hline S. cerevisiae
\end{tabular} \\
\hline T. viride & 22.1 & 218.3 & 22.3 & 346.0 & 45.4 & 167.0 \\
\hline B. subtilis & 19.1 & 280.0 & 18.0 & 260.0 & 62.1 & 265.3 \\
\hline P. fluorescens & 20.0 & 233.3 & 24.9 & 398.0 & 43.7 & 157.0 \\
\hline Vitavax-200 & 9.3 & 55.0 & 13.0 & 140.0 & 29.7 & 74.7 \\
\hline Control & 6.0 & ------- & 5.0 & ------ & 17.0 & ----- \\
\hline
\end{tabular}

1- Chitinase activity was expresses as $\mathrm{mM} \mathrm{N}$-acetyl glucose amine equivalent released / gram fresh weight tissue / 60 minutes.

2- Peroxidase activity was expressed as the change in absorbance (O.D) / minute/gram fresh weight.

3- The polyphenoloxidase activity was assayed as the change in absorbency (O.D)/ minute/gram fresh weight.

Effect of four bioagents compared to the fungicide Vitavax-200 on incidence of bean damping-off under field conditions:

The four bioagents, i.e. yeast (S. cerevisiae), T. viride, B. subtilis and $P$. fluorescens, were tested for their effect on incidence of damping-off under field conditions in two successive seasons 2009 and 2010. Data shown in Table (5) indicate that Vitavax-200 fungicide and all bioagents significantly reduced the 
Table 5. Effect of four bioagents on incidence of damping-off of bean plants (Bronco cv.) under field conditions during 2009 and 2010 seasons

\begin{tabular}{|c|c|c|c|c|c|c|}
\hline & Treatment & $\begin{array}{c}\text { Pre-emergence } \\
\text { damping-off } \\
(\%)\end{array}$ & $\begin{array}{c}\text { Reduction } \\
(\%)\end{array}$ & $\begin{array}{c}\text { Post- } \\
\text { emergence } \\
\text { damping-off } \\
(\%)\end{array}$ & $\begin{array}{c}\text { Reduction } \\
(\%)\end{array}$ & $\begin{array}{c}\text { Survived } \\
\text { plants (\%) }\end{array}$ \\
\hline \multirow{6}{*}{ 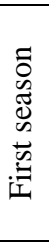 } & S. cerevisiae & $11.5 \mathrm{bc}$ & 71.7 & $10.3 \mathrm{bc}$ & 50.5 & $78.2 \mathrm{a}$ \\
\hline & T. viride & $15.7 \mathrm{~b}$ & 61.3 & $7.6 \mathrm{c}$ & 63.5 & $76.8 \mathrm{a}$ \\
\hline & B. subtilis & $13.9 \mathrm{bc}$ & 65.7 & $10.9 \mathrm{bc}$ & 47.6 & $75.2 \mathrm{a}$ \\
\hline & P. fluorescens & $8.9 \mathrm{c}$ & 78.1 & $12.2 \mathrm{~b}$ & 41.3 & $79.0 \mathrm{a}$ \\
\hline & Vitavax-200 & $11.5 \mathrm{bc}$ & 71.7 & $8.0 \mathrm{c}$ & 61.5 & $80.5 \mathrm{a}$ \\
\hline & Control & $40.6 \mathrm{a}$ & 0.0 & $20.8 \mathrm{a}$ & 0.0 & $38.5 \mathrm{~b}$ \\
\hline \multirow{6}{*}{ 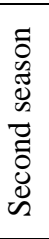 } & S. cerevisiae & $24.0 \mathrm{~b}$ & 47.6 & $5.2 \mathrm{~b}$ & 63.4 & $70.8 \mathrm{~b}$ \\
\hline & T. viride & $18.1 \mathrm{~b}$ & 60.5 & $2.8 \mathrm{~b}$ & 80.3 & $79.2 \mathrm{a}$ \\
\hline & B. subtilis & $25.1 \mathrm{~b}$ & 45.2 & $4.2 \mathrm{~b}$ & 70.4 & $70.8 \mathrm{~b}$ \\
\hline & P. fluorescens & $25.0 \mathrm{~b}$ & 45.4 & $4.9 \mathrm{~b}$ & 65.5 & $70.1 \mathrm{~b}$ \\
\hline & Vitavax-200 & $25.0 \mathrm{~b}$ & 45.4 & $4.2 \mathrm{~b}$ & 70.4 & $70.8 \mathrm{~b}$ \\
\hline & Control & $45.8 \mathrm{a}$ & 0.00 & $14.2 \mathrm{a}$ & 0.00 & $39.9 \mathrm{c}$ \\
\hline
\end{tabular}

Values with the same letter are not significantly different $(\mathrm{P}=0.05)$.

disease. As for first season 2009, the most effective treatments were B. subtilis, $T$. viride, S. cerevisiae, $P$. fluorescens and Vitavax-200 fungicide, which reduced the disease more than 61.3 and $41.4 \%$ for pre- and post-emergence, respectively. The corresponding percentages of survived plants for these bioagents were 78.2, 79.0, $75.2,76.8$ and $80.5 \%$, respectively, with no significant between them viz. $38.5 \%$ for the control. On the other hand, T. viride was the most significant effective treatment for decreasing pre- and post-emergence damping-off and increasing survived plants compared with the others, which gave $79.2 \%$ of survived plants followed by the other treatment with no significant in between, viz. $39.9 \%$ for the control in the second season 2010 .

Effect of four bioagents compared to the fungicide Vitavax-200 on fresh and dry weight for shoot and root system and seed yield of bean plants under field conditions:

The four bioagents were evaluated for their effect on some crop parameters of bean plants under field conditions in two growing seasons 2009 and 2010. Data shown in Table (6) indicate that all bioagents and Vitavax-200 significantly increased the assessed crop parameters of bean plants under field conditions as compared to untreated plants (control) in the two seasons. The highest increase of all assessed crop parameters except for seed yield was obtained with $S$. cerevisiae, which increased the shoot system fresh weight, shoot system dry weight, the root system fresh weight and root system dry weight, $\left(105.3,29.4,18.7\right.$, and 6.9 g plant $^{-1}$, respectively), however, Vitavax-200 fungicide was the most effective treatment for increasing seed yield production $(1048.3 \mathrm{~kg} / \mathrm{feddan})$, in the first season; while, $100.3,37.9,23.3,8.6 \mathrm{~g} \mathrm{plant}^{-1}$ and $1142.2 \mathrm{~kg}$ feddan $^{-1}$, respectively, in the second season. The same trend was obtained during the second season 2010 with few exceptions. 
Table 6. Effect of different bioagents on fresh and dry weight for shoot and root system and seed yield of bean plants (cv. Bronco) under field conditions during 2009 and 2010 growing seasons

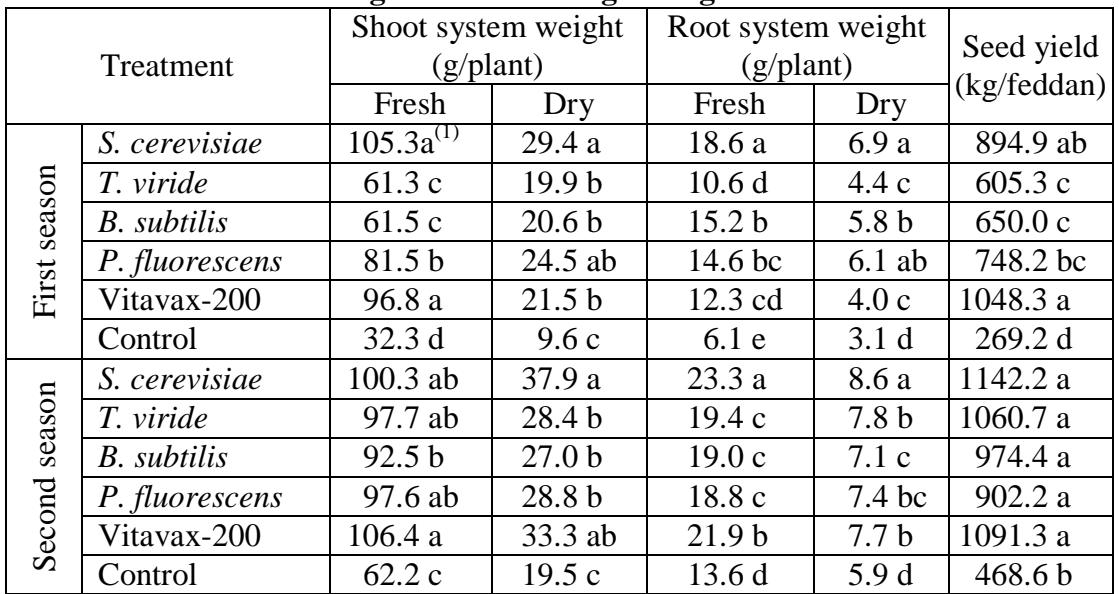

Values with the same letter are not significantly different $(\mathrm{P}=0.05)$.

\section{D i s c us s i on}

Bean (Phaseolus vulgaris L.) is one of the most important leguminous crops in Egypt for local consumption and exportation. Damping-off and root-rot diseases are serious and persistent problem for bean plants during growing season (Filion et al., 2003; Harveson et al., 2005 and Wen et al., 2005). Sclerotium rolfsii causes the disease known as southern blight in a wide variety of crops. Due to the pollution of the human food by agrochemicals, especially pesticides, therefore there is a growing need to develop alternative approaches for controlling plants diseases rather than pesticides. So, bioagents are risk free both for environment and non-target organisms, and could reduce the use of chemical products for controlling plant diseases. Most bioagents have varied performance in different environmental conditions. Some of this variability has been attributed to differences in physical and chemical properties found in natural environments where bioagents are applied (Thomashow and Weller, 1996 and Duffy et al., 1997).

In the present study, under greenhouse conditions results indicated that all the tested bioagents significantly reduced the incidence of bean damping-off caused by $S$. rolfsii with significant increase to shoot and root dry and fresh weight. In addition, all the tested bioagents caused considerable increased in the activity of peroxides, polyphenoloxidase and chitinase. Furthermore, under field conditions results of two successive seasons showed that all bioagents have significantly reduced the disease and increased the produced seed yield. The most effective treatments were $S$. cerevisiae and B. subtilis, which increased the seed yield per feddan. Application of $S$. cerevisiae resulted in the highest reduction to pre- and post-emergence damping-off and increased the survived plants in comparison with 
the control. Hassan and Abd El-Rehim (2002) observed that increasing yeast concentration $(0.05$ to $0.1 \%)$ resulted in gradual reduction to onion neck rot. Lokesh et al. (2007) mentioned that using several taxa included yeast genera as plant growth promoters and/or as bioagents significantly reduced the infection of watermelon by Fusarium spp. and increased seed germination. In addition, bacterial species like Bacillus, Pseudomonas, have been proved in controlling the fungal diseases. Bacteria identified as plant growth promoting rhizobacteria and biocontrol strains often belong to the genera of Bacillus (Nair et al., 2002) and Pseudomonas (Mark et al., 2006). The mechanisms through which Pseudomonas spp. control plant diseases involve (i) competition for niches and nutrients, (ii) antibiosis, (iii) predation, and (iv) induction of plant defence responses. Biocontrol of damping-off diseases has been successfully applied using B. subtilis (Berger et al., 1996; Harris and Adkins, 1999; Georgakopoulos et al., 2002 and Schmidt et al., 2004). Fernando et al. (2007), in field studies over a period of two years, indicated that disease control with Pseudomonas chlororaphis (PA-23), Bacillus amyloliquefaciens (BS6) was comparable to that achieved with the fungicide Rovral (iprodione). They added that here was no significant difference between single- and double-spray application of PA-23 and BS6 in the management of canola stem rot.

Mukherjee and Raghu (1997) observed that Trichoderma spp., were highly effective in suppressing $S$. rolfsii on ginger rhizomes and on several vegetables in storage. Also, Rekha et al. (2012) found that isolates Tri-13 (T. viride) and Tri-29 ( $T$. viride) reduced the growth of $S$. rolfsii through volatile metabolites compare to other tested isolates and control. Similarly, Chakrabortys and Bhawmik (1985) found that $T$. harzianum and $T$. viride highly effective in the controlling of sunflower collar rot caused by $S$. rolfsii. In a conclusion, it could be suggested that bioagents as safety method could be commercially used for controlling bean damping-off disease under field conditions.

\section{Ref e r e n c es}

Abd-Alla, M.A.; El-Mohamedy, R.S.R. and El-Mougy, Nehal S. 2007. Control of sour rot disease of lime fruits using saprophytic isolates of yeast. Egypt. J. Phytopathol., 35(2): 39-51.

Abdel-Kader, M.M.; El-Mougy, Nehal S.; Aly, M.D.E. and Lashin, S.M. 2012. Different approaches of bio-control agents for controlling root-rot incidence of some vegetables under greenhouse conditions. Internat. J. Agric. Forestry, 2(1): 115-127.

Allam, A.I. and Hollis, J.P. 1972. Sulfide inhibition of oxidase in rice root. Phytopathology, 62: 634-636.

Anonymous, 2005. CoHort Software. Version 6.311. 798 Lighthouse Ave. PMB 320, Monterey, CA, 93940, USA.

Anonymous, 2007. Green beans integrated pest management. An ecological guide, F.A.O. Regional Vegetable IPM Programme. 
Berger, F.; Hong, Li.; White, D.; Frazer, R. and Lieifert, C. 1996. Effect of pathogen inoculum, antagonist density, and plant species on biological control of Phytophthora and Pythium damping-off by Bacillus subtilis cot 1 in high humidity fogging glasshouses. Phytopathology, 86: 428-433.

Boller, T. and Mauch, F. 1988. Colorimetric assay for chitinase. Methods in Enzymol., 161: 430-435.

Chakrabortys, S. and Bhawmik, T.P. 1985. Chemical and biological control of Sclerotium rolfsii. Pesticides, 19(2): 31-33.

Duffy, B.K.; Ownley, B.H. and Weller, D.M. 1997. Soil chemical and physical properties associated with suppression of take-all of wheat by Trichoderma koningii. Phytopathology, 87: 1118-1124.

Duncan, D.B. 1955. Multiple Range and Multiple F-test. Biometrics, 11: 1-42.

El-Fiki, A.I.I.; Mohamed F.G.; El-Deeb, A.A. and Khalifa, M.M.A. 2004. Some applicable methods for controlling sesame charcoal rot disease (Macrophpmina phaseolina) under greenhouse conditions. Egypt. J. Phytopathol., 32(1-2): 87-101.

El-Mougy, Nehal. S. 2001. Field application of certain biological and chemical approaches on controlling bean wilt disease. Egypt. J. Phytopathol., 29: 69-78.

Fernando, W.G.D.; Nakkeeran, S.; Zhang, Y. and Savchuk, S. 2007. Biological control of Sclerotinia sclerotiorum (Lib.) de Bary by Pseudomonas and Bacillus species on canola petals. Crop Protection, 26(2): 100-107.

Filion, M.M.; Arnaud, S.T. and Jabaji-Hare, S.H. 2003. Quantification of Fusarium solani and $F$. phaseoli in mycorrhizal bean plants and surrounding mycorrhizosphere soil using Real-Time Polymerase Chain Reaction and direct isolations on selective media. Phytopathology, 93: 229-235.

Georgakopoulos, D.G.; Fiddaman, P.; Leifert, C. and Malathrakis, N.E. 2002. Biological control of cucumber and sugar beet caused by Pythium ultimum with bacterial and antagonists. J. Appl. Microbiol., 92: 1078-1086.

Hassan, M.H.A. and Abd El-Rehim, G.H. 2002. Yeast application as a biofertilizer and biocontrol agent for onion neck rot disease in relation to bulb productivity and quality. Assiut J. Agric. Sci., 33(1): 241-251.

Harris, A.R. and Adkins, P.G. 1999. Versatility of fungal and bacterial isolates for fungal and bacterial isolates for control of damping-off disease caused by Rhizoctonia solani and Pythium spp. Biological control: theory and applications in pest management. Biol. Control, 15: 10-18.

Harveson, R.M.; Smith, J. and Stroup, W.W. 2005. Improving root health and yield of dry beans in the Nebraska Panhandle with a new technique for reducing soil compaction. Plant Dis., 89: 279-184. 
Ibrahim M.M.; Mahmoud, E.Y. and Saleh Wagida A.M. 2008. The ability of some antagonistic bacteria on control of peanut root-rot disease compared to fungicides efficiency. Minufiya J. Agric. Res., 33(5): 1107-1125.

Jayashree, K.; Shanmugam, V.; Raguchander, T.; Ramanathan, A. and Samiyappan, R. 2000. Evaluation of Pseudomonas fluorescens (Pf-1) against blackgram and sesame root-rot disease. J. Biol. Cont., 14: 55-61.

Karunanithi, K.; Muthusamy, M. and Seetharaman, K. 2000. Pyrolnitrin production by Pseudomonas fluorescens effective against Macrophomina phaseolina. Crop Res., 19: 368-370.

Khalifa, M.M.A.; Draz, Eetmad E.I. and Ibrahim, M.M. 2007. Charcoal rot of sunflower in Egypt: Performance of some various control measures on disease incidence and seed yield production. Egypt. J. Appl. Sci., 22(8B): 315-330

Khalifa, M.M.A.; Mahmoud, Noher A. and Abou-Zeid, N.M. 2013. Performance of some biofungicides on the most onion economic diseases compared to recommended fungicide in Egypt I- White rot disease control and economical feasibility. Egypt. J. Appl. Sci., 28(1): 40-65.

Kumar, P. T. 2007. Biological management of Alternaria blight of onion. M.Sc. College of Agric., Dharwad Univ. of Agric. Sci., Dharwad. 112pp.

Lokesh, S.; Bharath, B.G.; Raghavendra, V.B. and Govindappa, M. 2007. Importance of plant growth-promoting rhizobacteria in enhancing the seed germination and growth of watermelon attacked by fungal pathogens. Acta Agronomica Hungarica, 55(2): 243-249.

Mahmoud, E.Y.; Shokry, Samia Y.M. and Hussin, Zeinab N. 2006. Efficiency of some antagonistic bacteria to reduce incidence of damping-off, wilt and peanut root-rot. J. Agric. Sci. Mansoura Univ., 31(6): 3525-3536.

Mark, G.L.; Morrissey, J.P.; Higgins, P. and O'Gara, F. 2006. Molecular-based strategies to exploit Pseudomonas biocontrol strains for environmental biotechnology applications. FEMS Microbiol. Ecol., 56: 167-77.

Matta, A. and Diamond, C. 1963. Symptoms of Fusarium wilt in relation to quantity of fungus and enzyme activity in tomato stems. Phytopathology, 53: 574-587.

Meena, B.; Marimuthu, T.; Vidhyasekaran, P. and Velazhahan, R. 2001. Biological control of root-rots of groundnut with antagonistic Pseudomonas fluorescens strains. Z. Pflanzenkr. Pflanzensch., 108: 369-381. (C.f. CAB Abstracts, 2003).

Mukherjee, P.K. and Raghu, K. 1997. Trichoderma sp. as a microbial suppressive agent of Sclerotium rolfsii on vegetables. World J. Microbiol. Biotechnol., 13: 497-499.

Nair, J.R.; Singh, G. and Sekar, V. 2002. Isolation and characterization of a novel Bacillus strain from coffee phyllosphere showing antifungal activity. J. App. Microbiol., 93: 772-780. 
Omar, M.N.A.; Badr, Salwa F.; Hasan, Maggi E. and Hewait, Heba M. 2011. Evaluation of some plant growth-promoting rhizobacteria (PGPR) in inducing resistance of wheat leaf rust under saline conditions. Egypt. J. Phytopathol., 39(1):111-130.

Punja, Z.K. 1985. The biology, ecology and control of Sclerotium rolfsii. Ann. Rev. Phytopathol., 23: 97-127.

Rekha, D.; Patil, M.B.; Shetty, Shridhar P.; Swamy, K.M. and Rajini, Gamanagatti B. 2012. In vitro screening of native Trichoderma isolates against Sclerotium rolfsii causing collar rot of groundnut. Internat. J. Sci. \& Nature, 3(1): 117-120.

Schmidt, C.S.; Agostini, F.; Leifert, C.; Killham, K. and Mullins, C.E. 2004. Influence of soil temperature and metric potential on sugar beet seedling colonization and suppression of Pythium damping-off by the antagonistic bacteria Pseudomonas fluorescens and Bacillus subtilis. Phytopathology, 94: $351-363$.

Schwartz, H.F.; Steadman, J.R.; Hall, R. and Fors, R.L. 2005. Compendium of Bean Diseases. Amer. Phytopathol. Soc., ASP Press.

Thomashow, L.S. and Weller, D.M. 1996. Current concept in the use of introduced bacteria for biological disease control: mechanisms and antifungal metabolites. Pages: 187-235. In: Plant-Microbe Interactions. Stacey, G. and Keen, N.T. (eds.). Chapman \& Hall, NY, USA.

Tuzun, S; Rao, M.N.; Vogeli; Schardl, C.L. and Ku, J.A. 1989. Induced systemic resistance to blue mould: early induction and accumulation of $B, 1,3$-gluconases, Chitinase and other pathogenesis-related proteins (b-proteins) in immunized tobacco. Phytopathology, 79: 979-983.

Wen, K.; Sequin, P.; Arnaud, M.S. and Jabaji-Hare, S. 2005. Real-Time Quantitative RT-PCR of defence-associated gene transcripts of Rhizoctonia solani infected bean seedlings in response to inoculation with a non-pathogenic binucleate Rhizoctonia isolate. Phytopathology, 95(4): 345-353.

(Received 15/04/2014; in revised form 16/05/2014) 


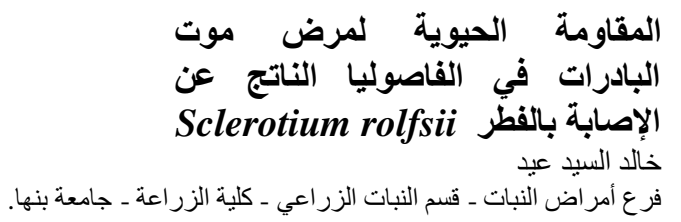

تم دراسة تأثثر أربعة من كائنات المكافحة الحيوية وهي الخميرة

وفطر Saccharomyces cerevisiae Pseudomonas fluorescens و لمكافحة مرض سقوط

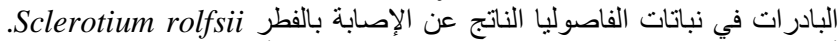

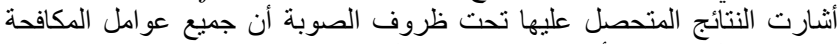

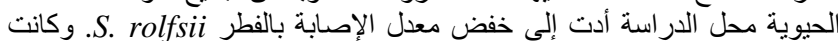

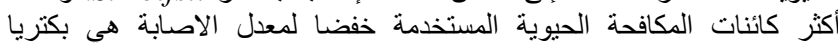

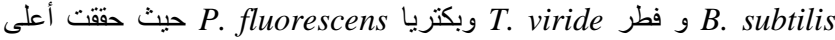

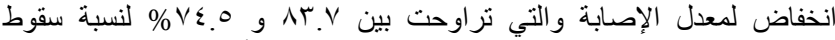

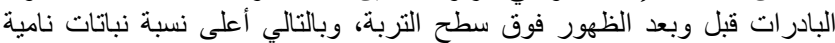

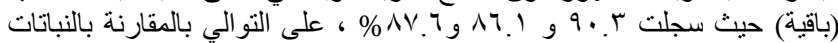

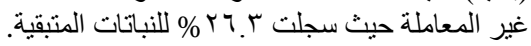

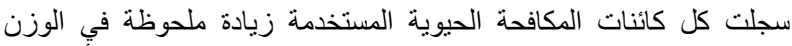

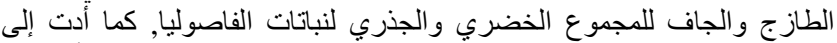

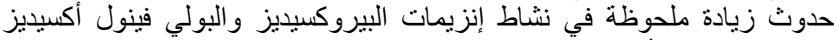

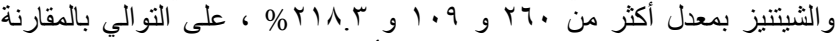

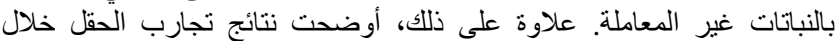

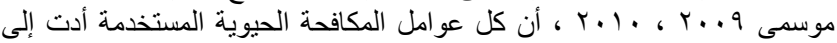

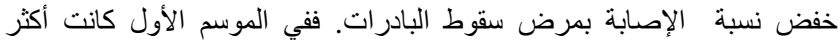

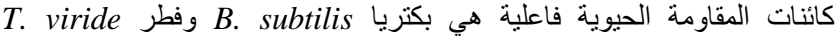

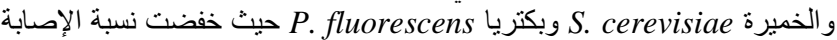

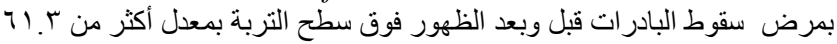

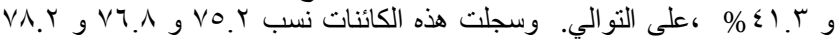

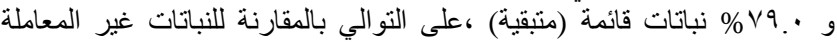

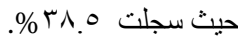

أما بالنسبة إلي المحصول فقد كانت أكثر المعاملات فاعلية هي الخميرة

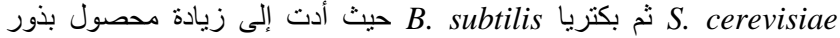

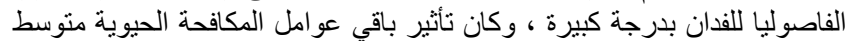

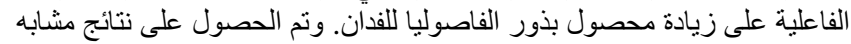

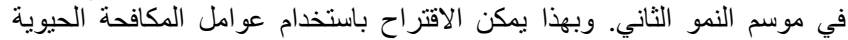
السابقة كطريقة واعدة وآمنة لمكافحة مرض سقوط الإنزاجة بالبادرات في نباتات الفاصوليا

المتسبب عن الإصابة بالفطر واعنة 